- DOI: $10.31866 / 2410-1311.36 .2020 .221059$

УДК 7.025.4:719

\title{
- РЕСТАВРАЦІЙНА ДІЯЛЬНІСТЬ І ГЛОБАЛЬНІ ЗАГРОЗИ: ТРАНСФОРМАЦІї ТЕОРЕТИЧНИХ КОНЦЕПЦІЙ
}

\section{- Рішняк Олег Богданович}

- Реставратор, керівник відділу реставрації живопису, ORCID: 0000-0002-2423-4843, e-mail: olegrishnyak@ukr.net, Український регіональний спеціалізований науково-реставраційний інститут «Укрзахідпроектреставрація», пл. Соборна, За, Львів, Україна, 79008

\section{- Для цитування:}

Рішняк, О.Б. (2020). Реставраційна діяльність і глобальні загрози: трансформації теоретичних концепцій. Питання культурології, (36), 156-165. doi: https://doi.org/10.31866/24101311.36.2020.221059.

\section{- Анотація}

Метою статті $є$ виявлення залежності збереження об'єктів культурної спадщини від їхньої суспільної цінності та висвітлення світових тенденцій розвитку реставраційної галузі. В методології використано загальнонаукові методи теоретичного дослідження, а також загальнологічні наукові методи аналізу, порівняння та пояснення. Комплексний підхід упредметнений у використанні методів вивчення історичних фрактів, підтверджених різними джерелами. Наукова новизна роботи полягає у дослідженні трансформацій реставраційних теоретичних концепцій, зумовлених глобальними економічними та політичними процесами. Розкрито залежність збереження творів мистецтва від їхньої соціальної цінності та підкреслено, що наукова значущість пам'ятки не завжди є достатнім аргументом для ії збереження. Висновки. У статті розглянуто реставраційну діяльність як складову культурного життя соціуму та визначено поняття суспільної цінності об'єктів мистецтва як її ідеологічну надбудову. Окреслено глобальні загрози для збереження світової культурної спадщини, досліджено впливи політичних та економічних чинників на схоронність об'єктів мистецтва. Звернено увагу на неоднозначність трактувань основних понять реставраційної науки представниками різних культур та необхідність створення універсальної пам'яткоохоронної доктрини. Репрезентовано альтернативні концепції теорії реставрації. Зазначено, що з огляду на небезпеки та виклики сьогодення, необхідно переосмислювати усталені постулати реставраційної діяльності, шукати ефрективні моделі інтеграції пам'яток в сучасний культурний контекст.

Ключові слова: реставрація; реставраційна діяльність; теорія реставрації; пам'ятка; об'єкт культурної спадщини 


\section{- Вступ}

Розвиток української реставраційної науки є неможливим без розуміння широкого діапазону світових процесів, що впливають на формування сучасної теорії реставрації. Глобальні загрози збереженню світової культурної спадщини вимагають переосмислення базових принципів реставраційної діяльності, пошуку нових концепцій та доктрин. Розуміння тенденцій розвитку світової пам'яткоохоронної галузі позитивно вплине на вирішення практичних завдань вітчизняної реставрації.

Небезпеки, що нависли над матеріальними об'єктами культурної спадщини зумовили пошуки нових теоретичних підходів до питань збереження та реставрації, основою яких стало поняття суспільної цінності пам'ятки. Це значення досліджувалось в працях В. Цитовича (2004), Ю. Боброва (2004). Витоки «західної» реставраційної доктрини вивчав А. Томашевський (1997). Важливий науковий внесок зробила В. Бєлозьорова (1995), запропонувавши типологічні моделі реставраційної діяльності. Проблемам збереження світової культурної спадщини присвятили свої дослідження Д. Ловенталь (Лоуэнталь, 2004), Дж. Стонер (Stoner, 2005), К. Кемерон (2017). Альтернативні теоретичні розробки та реставраційні концепції репрезентував С. Муньос-Віньяс (Muñoz-Viñas, 2002, 2005).

\section{- Мета статті}

Виявити залежність збереження об’єктів культурної спадщини від їхньої суспільної цінності, окреслити загрози, пов'язані зі світовими процесами глобалізації, позначити нові теоретичні концепції у пам'яткоохоронній галузі, висвітлити світові тенденції розвитку реставраційної діяльності. В методології використано загальнонаукові методи теоретичного дослідження, а також загальнологічні наукові методи аналізу, порівняння та пояснення. Комплексний підхід упредметнений у використанні методів вивчення історичних фактів, підтверджених різними джерелами.

\section{- Виклад матеріалу дослідження}

Реставраційну діяльність як діяльність людини, спрямовану на збереження результатів творчої праці попередніх поколінь, неможливо розглядати поза процесом розвитку світової культури. Адже саме культура $є$ наслідком всієї історії людської діяльності, своєрідною багатофункціональною інфраструктурою для існування людства.

У сучасній науці реставраційна діяльність розглядається у контексті динаміки культури, ідея якої в науковий обіг була введена ще у 1930-х роках XX століття (Сорокин, 1992).

Цей термін визначає зміни у світовій культурі, як результат взаємодії різноманітних культур, що характеризуються цілісністю та упорядкованістю тенденцій, де сумісні дії учасників процесу відбуваються в одному хронологічному і культурному просторі, та передбачають часову взаємодію між теперішнім і минулим. Саме така взаємодія або «спадкоємність», «можлива лише за умови збереження самих матеріальних носіїв - пам'яток культури. При цьому відбувається включення пам'яток минулого в контекст сучасної культури» (Бобров, 2004, с. 69). 
Виходячи з такої настанови, реставраційна діяльність $є$ ніщо інше, як спосіб фізичної реалізації процесу культурної спадкоємності. Цей вид людської діяльності спрямований не тільки на збереження матеріальних, а й духовних складових об'єктів мистецтва, і $є$ важливим чинником забезпечення комунікативної та інформаційної функцій культури. Відреставровані твори, що переходять від покоління до покоління, несуть у собі безцінну інфрормацію не лише про технічні можливості, а й про всі інші аспекти культурного розвитку - мистецький, соціальний, політичний та інші. У загальнокультурному процесі реставраційна діяльність розглядається не лише як сукупність наукових, технічних і художніх заходів, тобто односторонніх впливів суб'єкта на об'єкт, а як особливий вид людської діяльності, що є процесом активної взаємодії суб'єкта з об'єктом.

Реставрація як самостійна наукова дисципліна виокремилась на зламі XIX-XX століть. Результатом наукових напрацювань стала низка міжнародних та національних документів, хартій, декларацій, законів та норм, у яких були прописані основні поняття та головні принципи реставраційної діяльності. Слід зауважити, що більшість міжнародних правових актів, прийнятих у першій половині XX століття насамперед стосувалась архітектурних пам'яток. Проте загальні принципи, зафріксовані в цих документах, стали базовими при розробці положень щодо реставрації інших видів об'єктів культурної спадщини. Так, «Міжнародна хартія з охорони та реставрації нерухомих пам'яток і визначних місць (Венеційська хартія)» (1964) стала ідеологічною основою для прийняття низки інших міжнародних та національних документів у сфері збереження та реставрації пам'яток ("Міжнародна хартія", 2009, с. 334-336).

Реставраційна діяльність, як будь-яка інша праця людини в соціальному середовищі, невіддільно поєднана з усіма аспектами сучасного життя: політикою, економікою, наукою, культурою. Незважаючи на її специфіку, виражену в одночасному спрямуванні реставраційної справи у минуле, теперішнє та майбутнє, в поєднанні об'єктивістських наукових принципів із суб'єктивною шкалою цінностей та творчих підходів (Цитович, 2004), вона є залежною від різноманітних суспільних процесів, не завжди безпосередньо пов'язаних з культурною спадщиною. Суспільство формує соціальний запит на реставраційну діяльність і визначає основні ії̈ завдання. У цьому контексті реставратору відводиться роль виконавця певного соціального замовлення, мотивом якого завжди є суб'єктивний ціннісний підхід.

Розглядаючи реставраційну діяльність як складову культурного життя суспільства, світовій пам'яткоохоронній галузі необхідно окреслити найхарактерніші глобальні проблеми і загальні тенденції для їх вирішення.

Поняття суспільної цінності, що є своєрідною надбудовою реставраційної діяльності та визначає ії мотив, сьогодні великою мірою залежить від політичного й економічного аспектів. Політичний аспект базується на відношенні тих чи інших суспільних фрормацій до творів минулого. Оскільки об'єкти культурної спадщини у широкому розумінні є матеріальним виявом багатовікової історії та духовності народів, то політика окремих соціальних груп стосовно культурних артефактів часто $€$ неоднозначною. Політичні мотиви можуть активувати реставраційну діяльність з метою збереження або виключати з суспільної свідомо- 
сті значні культурні пласти. Більшовицька «культурна зачистка» у першій половині XX століття, заради торжества комуністичної ідеології, вилилась в масове нищення культурної спадщини багатьох народів. XXI століття також багате прикладами руйнування визначних творів світової культури з політичних чи релігійних мотивів. Серед найбільш значущих - знищені статуї Будди в Баміанській долині (Афрганістан, 2001), мавзолеї святих суфіїв у м. Тімбукту (Малі, 2012), пам'ятки Пальміри (Сирія, 2015) (Кемерон, 2017).

Засудження комуністичної ідеології та процес декомунізації, як політичний чинник, також торкнулись багатьох мистецьких творів доби тоталітаризму. Були демонтовані з первісних місць розташування та перенесені у музеї пам'ятники Подяки радянським солдатам у Щецині та Варшаві (Польща, 2017, 2020), маршалу І. Конєву в Празі (Чехія, 2020), триває суспільна дискусія про долю монумента М. Щорсу в Києві. Багато високохудожніх творів, створених талановитими художниками, яким довелось працювати в умовах тоталітарного режиму, можуть бути втрачені через їх ідеологічне забарвлення. 3 іншого боку, світові політичні процеси кінця XX століття такі, як падіння Берлінської стіни, розпад Радянського Союзу, конфлікт на Балканах, змістили поняття цінності культурної спадщини в сторону їхніх символічних значень. Саме в контексті нематеріальної цінності відбувались реставраційні відтворення моста в м. Мостарі (Боснія та Герцеговина, 2004), соборів Фрауенкірхе в Мюнхені та Дрездені (Німеччина, 1994, 2005). Політична воля та бажання українського суспільства повернути свої втрачені духовні символи були причинами відбудови Михайлівського Золотоверхого (1998) та Успенського соборів (2000) у Києві, Володимирського собору в Севастополі (2004) та багатьох інших.

Сьогодні все очевиднішою $є$ перевага економічних інтересів над культурними цінностями. Великі інфраструктурні проєкти вимагають дедалі більшого простору для нового будівництва, спричиняючи руйнування як окремих пам'яток, так і цілих історичних територій. Якщо у 1960-х затоплення археологічної зони Нубії (Єгипет) при будівництві Асуанської греблі мало широкий міжнародний резонанс, то знищення 2020 року аналогічним способом пам'яток Хасанкейфа одного з найстаріших заселених міст на Землі, трактувалось, як внутрішня справа Туреччини. Вже розпочато будівництво греблі Діамер-Бхаша в Пакистані, що прогнозовано спричинить затоплення значної території вздовж Каракорумського шосе, відомої скелями та валунами, що містять цінні петрогліфи согдійської, скіфрької та тібетської епох. Невідворотні процеси урбанізації змінюють архітектурне середовище міст. Нове будівництво в міських історичних ареалах стало звичним явищем. Задля досягнення сучасних стандартів комфорту, історичні будівлі піддаються агресивним реконструкціям та модернізаціям.

Глобальною небезпекою для пам'яток виявився масовий культурний туризм. Індустрія туризму, розглядаючи об'єкти культурної спадщини як джерело прибутку, не вимагає повною мірою ні правди, ні автентичності. Позитивне, за своєю суттю, суспільне явище, що давало можливість широкій аудиторії знайомитись зі світовою культурною спадщиною та осягати духовні багатства світової цивілізації, через непомірну комерціалізацію процесу применшило свою інтелектуальну складову. У контексті великого бізнесу пам'яткам відведено роль 
яскравих декорацій для відпочинкових шоу, за які глядач готовий платити гроші. Як приклади, можна згадати облаштування «Лабораторії алхіміка» у підвалах Підгорецького замку (Львівщина) чи нічні екскурсії підземеллями Львова, з театралізованими постановками та містичними розповідями, що звучать з уст екскурсоводів. Як влучно зауважив американський історик Д. Ловенталь (Лоуэнталь, 2004): «Минуле - це чужа країна, в яку поринув цілий потік туристів. Минуле випробовує на собі всі звичні наслідки популярності. Що більше його цінують саме в собі, то менш реальним та достовірним воно стає» (с. 13). Незважаючи на це, розвиток туристичної галузі сприймається як позитивний економічний чинник і аргумент на користь збереження пам'яток, можливість їхнього включення у сучасний культурний простір. «Реставраторам <...> треба дивитись на збереження значно ширше, враховуючи приналежність пам'яток до певної культури і умови економічного виживання у XXI столітті» (Stoner, 2005).

Проблема забруднення довкілля, що традиційно розглядалась у контексті охорони здоров'я та життєдіяльності, сьогодні також торкнулась збереження пам'яток. Шкідливі гази й агресивні хімічні домішки в складі атмосферного повітря призводять до руйнації пам'яток архітектури (Цигичко, 2012).

Глобальні загрози сучасності визначили необхідність пошуку універсальної пам'яткоохоронної доктрини, яка б стала в однаковій мірі прийнятною для усіх країн світу. Концепція єдиного культурного простору загострила кризу західної фрілософії збереження, яка головним чином ґрунтується на автентичності матеріальної сутності. Джерелом цієї світоглядної парадигми стала християнська традиція культу мощів святих та реліквій античної архітектури, справжність яких визначалась виключно автентичністю матеріальних структур (Tomaszewski, 1997, с. 103). Натомість для народів Далекого Сходу матеріальна достовірність творів не має визначального значення. Поняття автентичності там перш за все пов'язується з художньою формою, символічністю значень, духовним змістом (Бобров, 2004, с. 14). Розбіжності в підходах до збереження пам'яток виявились настільки разючими, що 1994 року питанням автентичності було присвячено конференцію в м. Нарі (Японія), на якій поняття автентичності форми було прирівняне до автентичності матеріалу. В контексті реставраційної діяльності радикальність Нарського документу виявилась лише на папері. У «західній» реставраційній практиці відбудови та відтворення зруйнованих пам'яток у їхніх первісних формах з політичних, патріотичних, релігійних та інших мотивів були і залишаються поширеним явищем.

Водночас із пошуком нових рішень практичних завдань реставрації, починається формування і нової теоретичної бази, яка була б універсальною щодо збереження творів різних видів мистецтв і предметів, які є культурними цінностями. Ще у 1995 році В. Бєлозьорова виокремила дві типологічні моделі сучасних напрямів у реставрації. Автор стверджує, що перша типологічна модель «приймає принцип, згідно з яким духовна субстанція пам'ятки незнищенна і може постійно відроджувати втрати в складі свого матеріального втілення і так продовжувати існування пам'ятки в часі» (Белозерова, 1995, с. 7). Згідно з другим варіантом «духовна субстанція пам'ятки невіддільна від свого матеріального втілення і з часом зникає разом із руйнуванням авторської форми» (Белозерова, 1995, 
с. 7). Обидві моделі об'єднують два аспекти - це визнання, що історичні нашарування можуть мати окремий науковий інтерес і що будь-які реставраційні операції вносять непоправні зміни в матеріальну структуру пам'ятки (Белозерова, 1995, с. 11-12). Теорія наукової реставрації здебільшого використовує другу типологічну модель. I хоча в науковому просторі існує думка, що «твердження про можливість двох точок зору на цілі і завдання реставрації - це розмивання ії наукових принципів» (Зверев, 2005, с. 24), все ж дослідниця визнає, що в певних ситуаціях, коли цього вимагають політичні чи символічні пріоритети, може бути оправдане застосування і першої моделі.

Розвиваючи ідею соціалізації збереження культурної спадщини, С. МуньосВіньяс у 2005 році порушив питання суспільного компромісу у сучасній теорії реставрації, запропонувавши термін «адаптивна етика» (Muñoz-Viñas, 2005, c. 209). Ця концепція пропонує розглядати реставраційну діяльність не лише як взаємодію суб'єкта з об'єктом, але і як форму діалогу для врахування інтересів всіх зацікавлених сторін. Такими учасниками, крім науковців та працівників пам'яткоохоронної сфери, можуть бути представники різних соціальних груп, наприклад, менеджери туристичної індустрії, ресторанного та готельного бізнесу, економісти, користувачі чи власники творів мистецтва.

Основна ідея нового бачення полягає в тому, що будь-який процес збереження повинен відбуватися не лише заради об'єктів мистецтва, а й для суб'єктів, як окремих осіб, так і суспільних угруповань. Це кардинально відрізняє нову концепцію від всіх попередніх теоретичних напрацювань в галузі охорони пам'яток. Завдання наукової спільноти полягає в інтерпретації значення об'єктів культурної спадщини для решти суспільства (Muñoz-Viñas, 2005, с. 209). Під впливом нових поглядів у науці формується таке поняття, як «переговорна реставрація», згідно з яким рішення про заходи з охорони пам'яток не повинні нав'язуватися, а лише погоджуватися між зацікавленими суб'єктами (Muñoz-Viñas, 2002, с. 30).

Проте у пам'яткоохоронному середовищі існує розуміння того, що ідея соціалізації збереження потенційно несе у собі серйозні ризики відходу від наукової методології і створює низку загроз для об'єктів культурної спадщини. Тому на противагу цій ідеї постає концепція «сталого збереження», що передбачає пристосування мистецьких об'єктів з огляду на користувачів у майбутньому. У запропонованій концепції головна роль відводиться саме користувачам з майбутнього і від їхнього імені повинні виступати сьогоднішні експерти (Muñoz-Viñas, 2002, с. 31).

Отже, сучасна теорія реставрації ще остаточно не сорормована і перебуває в процесі активного наукового становлення. Існуючі нові наукові розробки намагаються не лише методологічно проаналізувати шляхи розвитку галузі, а й спрогнозувати майбутні напрями. Світові процеси глобалізації все більше впливають на сореру культурної спадщини, що за сучасним визначенням включає «всі об'єкти, будівлі та середовища, які суспільство наділяє особливими естетичними, художніми, документальними, екологічними, історичними, науковими, соціальними чи духовними цінностями і становлять матеріальне та культурне надбання, що повинно передаватись наступним поколінням» (European Confederation of Conservator-Restorers' Organisations, 2001, c. 39). 


\section{- Висновки}

У статті досліджено залежність реставраційної діяльності як форми збереження матеріальних об'єктів культурної спадщини від соціальних, політичних, економічних чинників. З'ясовано, що саме політичні чинники, з одного боку, призвели до масштабних руйнувань пам'яток в зонах військових конорліктів, а з іншого стали причиною відтворення великої кількості мистецьких об'єктів у різних частинах світу. Показано, що вагомими чинниками, які впливають на збереження культурної спадщини, $є$ економічні пріоритети у розвитку різних країн. Економічне підґрунтя мають такі небезпеки, як великі інфраструктурні проєкти на історичних територіях, урбанізація, екологічне забруднення, культурний туризм. У цьому контексті поняття суспільної цінності стає визначальним засобом збереження, що формує мотив реставраційної діяльності, відводячи реставратору роль виконавця суспільного замовлення.

Засвідчено, що глобальні загрози вимагають нових теоретичних підходів до питань збереження та реставрації об'єктів культурної спадщини, а також нестандартних практичних рішень. Відбувається переосмислення базових принципів реставраційної науки та пошук нових теоретичних моделей, які б більшою мірою відповідали потребам сучасності. В питаннях охорони культурної спадщини визначальним чинником стає суспільна значущість об'єкта мистецтва, його загальнокультурний контекст. Тільки інтеграція творів минулого в сучасне політичне, економічне та культурне життя може бути запорукою їхнього довготривалого збереження.

\section{- Список використаних джерел}

Белозерова, В. Г. (1995). Анализ типологических моделей современных направлений в реставрации. Художественное наследие: хранение, исследование, реставрация, 16, 4-18.

Бобров, Ю. Г. (2004). Теория реставрации памятников искусства: закономерности и противоречия. Эдсмит.

Зверев, В. В. (2005). Реставрация: слово и термин. Художественное наследие: хранение, исследование, рестарация, 22, 19-25.

Кемерон, К. (2017). Нужно ли восстанавливать всемирное наследие? Курьер ЮНЕСКО, 2, 56-59.

Лоуэнталь, Д. (2004). Прошлое - чужая страна (А. Говорунов, Пер.). Владимир Даль. Русский остров.

Міжнародна хартія з охорони та реставрації нерухомих пам'яток і визначних місць (Венеційська хартія). (2009). В Пам'яткознавство: правова охорона культурних надбань (с. 334-336). Інститут культурології Академії мистецтв України.

Сорокин, П. (1992). Человек. Цивилизация. Общество. Политиздат.

Цигичко, С. П. (2012). Екологія в архітектурі і містобудуванні. Харківська національна академія міського господарства.

Цитович, В. І. (2004). Реставрація між парадигмою і теорією. Пам'ятки України: історія та культура, 2, 30-57.

European Confederation of Conservator-Restorers' Organisations. (2001). Recommendation and Guidelines for the adoption of common principles regarding the conservation- 
restoration of cultural heritage in Europe. http://www.ecco-eu.org/fileadmin/assets/ documents/Others/APELRecommendation_and_Guidelines.pdf.

Muñoz-Viñas, S. (2002). Contemporary theory of conservation. Reviews in Conservation, 3 , 25-34.

Muñoz-Viñas, S. (2005). Contemporary Theory of Conservation. Elsevier ButterworthHeinemann.

Stoner, J. H. (2005). Changing Approaches in Art Conservation: 1925 to the Present. In Scientific Examination of Art: Modern Techniques in Conservation and Analysis (pp. 40-57). https://www.nap.edu/read/11413/chapter/5.

Tomaszewski, A. (1997). Na przełomie tysiącleci: międzynarodowa sytuacja konserwacji zabytków. Ochrona Zabytków, 50(2), 103-109.

\section{References}

Belozerova, V. G. (1995). Analiz tipologicheskikh modelei sovremennykh napravlenii v restavratsii [Analysis of typological models of modern trends in restoration]. Khudozhestvennoe nasledie: khranenie, issledovanie, restavratsiya, 16, 4-18 [in Russian].

Bobrov, Yu. G. (2004). Teoriya restavratsii pamyatnikov iskusstva: zakonomernosti $i$ protivorechiya [Theory of restoration of monuments of art: patterns and contradictions]. Edsmit [in Russian].

Cameron, C. (2017). Nuzhno li vosstanavlivat' vsemirnoe nasledie? [Do we need to restore the world heritage?] The UNESCO Courier, 2, 56-59 [in Russian].

European Confederation of Conservator-Restorers' Organisations. (2001). Recommendation and Guidelines for the adoption of common principles regarding the conservationrestoration of cultural heritage in Europe. http://www.ecco-eu.org/fileadmin/assets/ documents/Others/APELRecommendation_and_Guidelines.pdf [in English].

Lowenthal, D. (2004). Proshloe - chuzhaya strana [The Past is a Foreign Country]. Vladimir Dal. Russkii ostrov [in Russian].

Mizhnarodna khartiia z okhorony ta restavratsii nerukhomykh pam'iatok i vyznachnykh mists (Venetsiiska khartiia) [International charter for the conservation and restoration of monuments and sites (The Venice Charter)]. (2009). In Pamiatkoznavstvo: pravova okhorona kulturnykh nadban. Institute for Cultural Research of the National Academy of Arts of Ukraine [in Ukrainian].

Muñoz-Viñas, S. (2005). Contemporary Theory of Conservation. Elsevier ButterworthHeinemann [in English]

Muñoz-Viñas, S. (2002). Contemporary theory of conservation. Reviews in Conservation, 3, 25-34 [in English].

Sorokin, P. (1992). Chelovek. Tsivilizatsiya. Obshchestvo [Man. Civilization. Society]. Polytyzdat [in Russian].

Stoner, J. H. (2005). Changing Approaches in Art Conservation: 1925 to the Present. In Scientific Examination of Art: Modern Techniques in Conservation and Analysis (pp. 40-57). https://www.nap.edu/read/11413/chapter/5 [in English].

Tomaszewski, A. (1997). Na przełomie tysiącleci: międzynarodowa sytuacja konserwacji zabytków. Ochrona Zabytków, 50(2), 103-109 [in Polish].

Tsyhychko, S. P. (2012). Ekolohiia v arkhitekturi i mistobuduvanni [Ecology in architecture and urban planning]. O. M. Beketov National University of Urban Economy in Kharkiv [in Ukrainian]. 
Tsytovych, V. I. (2004). Restavratsiia mizh paradyhmoiu i teoriieiu [Restoration of the paradigm and theory]. Pam'iatky Ukrainy: istoriia ta kultura, 2, 30-57 [in Ukrainian].

Zverev, V. V. (2005). Restavratsiya: slovo i termin [Restoration: a word and a term]. Khudozhestvennoe nasledie: khranenie, issledovanie, restaratsiya, 22, 19-25 [in Russian].

\section{RESTORATION ACTIVITY AND GLOBAL THREATS: TRANSFORMATIONS OF THEORETICAL CONCEPTS}

\section{- Oleh Rishniak}

- Restorer, Head of the Painting Restoration Department, ORCID: 0000-0002-2423-4843, e-mail: olegrishnyak@ukr.net, Ukrainian Regional Specialized Research and Restoration Institute "Ukrzakhidproektrestavratsiia", Lviv, Ukraine

\section{- Abstract}

The purpose of the article is to study the dependence of the cultural heritage objects preservation on their social value and highlight the global trends in the restoration industry. The research methodology applies the general scientific methods of theoretical research, as well as general logical scientific methods of analysis, comparison and explanation. An integrated approach consists in the use of the methods of studying of the historical facts, confirmed by various sources. The scientific novelty of the work lies in the study of transformations of restoration theoretical concepts due to global economic and political processes. The dependence of the preservation of works of art on their social value is revealed and it is emphasized that the scientific significance of the monument is not always a sufficient argument for its preservation. Conclusions. The article considers the restoration activity as a component of the cultural life of modern society and defines the concept of the social value of art objects as its ideological superstructure. The author of the article defines the global threats to the preservation of the world cultural heritage and studies the influences of political and economic factors on the preservation of art objects. Particular attention is paid to the ambiguity of interpretations of the basic concepts of restoration science by representatives of different cultures and the need to create a universal heritage protection doctrine. Alternative concepts of modern restoration theory are presented. The author points out that considering the dangers and challenges of our time, it is necessary to rethink the established postulates of restoration activities, to look for effective models for cultural heritage integration into the modern cultural context.

Keywords: restoration; restoration activities; restoration theory; monument; an object of cultural heritage 


\title{
РЕСТАВРАЦИОННАЯ ДЕЯТЕЛЬНОСТЬ И ГЛОБАЛЬНЫЕ ВЫЗОВЫ: ТРАНСФОРМАЦИИ ТЕОРЕТИЧЕСКИХ КОНЦЕПЦИЙ
}

\author{
- Ришняк Олег Богданович \\ - Реставратор, руководитель отдела реставрации живописи, \\ ORCID: 0000-0002-2423-4843, e-mail: olegrishnyak@ukr.net, \\ Украинский региональный специализированный научно-реставрационный институт \\ «Укрзахидпроектреставрация», \\ Львов, Украина
}

\section{- Аннотация}

Целью статьи является исследование зависимости сохранения объектов культурного наследия от их общественной ценности и освещение мировых тенденций развития реставрационной отрасли. В методологии использованы общенаучные методы теоретического исследования, а также логические научные методы анализа, сравнения и объяснения. Комплексный подход проявился в использовании методов изучения исторических фрактов, подтвержденных различными источниками. Научная новизна работы заключается в исследовании трансформаций реставрационных теоретических концепций, обусловленных глобальными экономическими и политическими процессами. Раскрыта зависимость сохранения произведений искусства от их социальной ценности и подчеркнуто, что научная значимость памятника не всегда является достаточным аргументом для его сохранения. Выводы. В статье рассмотрена реставрационная деятельность как составляющая культурной жизни социума и определено понятие общественной ценности объектов искусства как ее идеологическая надстройка. Определены глобальные угрозы для сохранения мирового культурного наследия, исследованы влияния политических и экономических фракторов на сохранность объектов искусства. Обращено внимание на неоднозначность трактовок основных понятий реставрационной науки представителями различных культур и необходимость создания универсальной доктрины охраны памятников. Представлены альтернативные концепции теории реставрации. Отмечено, что учитывая опасности современности, необходимо переосмысливать устоявшиеся постулаты реставрационной деятельности, искать эфффективные модели интеграции памятников в современный культурный контекст.

Ключевые слова: реставрация; реставрационная деятельность; теория реставрации; памятник; объект культурного наследия 